\title{
Understanding success and psychological well-being of gifted kids and adolescents: Focusing on strengths of the heart
}

\author{
Entendendo o sucesso e o bem-estar psicológico de crianças \\ e adolescentes superdotados: concentrando-se \\ nas forças do coração
}

Steven I. PFEIFFER ${ }^{1}$ (ID) 0000-0001-5169-9665

\begin{abstract}
This article describes the work that the author has been focusing on over the last 15 years: understanding the social and emotional world of the gifted child and adolescent. The article describes the history behind how the author came to develop his thinking on the now popular concept, "strengths of the heart". Strengths of the heart include a triad of psychological concepts: social skills, emotional intelligence, and character strengths and virtues. Together, this triad of psychological concepts, strengths of the heart, predict to important life outcomes, including success, psychological health, happiness, and subjective well-being.
\end{abstract}

Keywords: Emotional intelligence; Gifted; Socioemotional development.

\section{Resumo}

Este artigo descreve o trabalho em que o autor tem se focado nos últimos 15 anos: compreender o mundo social e emocional da criança e do adolescente superdotados. O artigo descreve a história por trás de como o autor veio a desenvolver seu pensamento sobre o conceito atualmente disseminado de "forças do coração". O conceito de forças do coração inclui uma tríade de conceitos psicológicos: habilidades sociais, inteligência emocional e forças e virtudes do caráter. Conjuntamente, essa tríade de conceitos psicológicos, as forças do coração, antevê importantes resultados na vida do indivíduo, incluindo sucesso, saúde psicológica, felicidade e bem-estar subjetivo.

Palavras-chave: Inteligência emocional; Superdotados; Desenvolvimento socioemocional.

$\operatorname{rrv}$

1 Florida State University, College of Education, Department of Educational Psychology and Learning Systems. Stone Building 3206-H, 1114 W, Call Street, 32306-4453, Tallahassee, FL, United States. E-mail: <spfeiffer@fsu.edu>.

$\checkmark \nabla \nabla$

Como citar este artigo/How to cite this article

Pfeiffer, S. I. (2018). Understanding success and psychological well-being of gifted kids and adolescents: Focusing on strengths of the heart. Estudos de Psicologia (Campinas), 35(3), 259-263. http://dx.doi.org/10.1590/1982-02752018000300004 
In our research lab at Florida State University, and previously, in my work at Duke University, I focused on three areas of investigation related to gifted children and youth:

- How to identify high-ability children and adolescents beyond simply looking at a score on an Intelligence Quotient (IQ) test;

- Factors, in addition to cognitive and intellectual ability, that help us better understand and even predict the unfolding and development of talent at the highest levels of expertise and even eminence; and

- How and why success in life requires both strengths of the head - such as intelligence and creativity and problem-solving and planning ability, and strengths of the heart - such as emotional intelligence, compassion, empathy, zest-in-life, and gratitude.

Our various research investigations have been guided by my experiences working with highability children and youth in a variety of capacities for almost four decades (Pfeiffer, 2013a, 2013b, 2017). Trained as a clinician who started his career working with troubled children and youth, early in my professional life I became fascinated with prevention, early intervention, health promotion, resilience and invulnerability (Pfeiffer, 2009, 2017). This led to my growing interest, over the years, first as a practitioner and, later, as a professor and researcher, in understanding strengthbased psycho-educational and psychotherapeutic interventions in support of gifted children and adolescents who were at risk for a wide range of psychological problems and challenges, including underachievement, anxiety and depression, negative perfectionism, conduct problems, and peer relation difficulties (Pfeiffer, 2017).

In my early work while a Professor and head of the gifted program at Duke University, I considered the construct Emotional Intelligence (EI) as a possible preventive remedy or intervention in dealing with the general malaise affecting a significant number of gifted youth. I thought that if we could help all gifted youth develop strong levels of emotional intelligence, then perhaps this might be the generic and all-encompassing prophylactic or cure-all to protect gifted youth from social and emotional problems that all adolescents are susceptible to (Pfeiffer, 2001, 2015). In other words, I hypothesized that emotional intelligence might be the all-powerful psychological construct that could make a real difference in the success, quality of life, and overall well-being of all gifted adolescents (Pfeiffer, 2001).

Based on accumulated clinical experience and a growing body of research on emotional intelligence, however, I came to adjust my view on emotional intelligence. I came to understand that emotional intelligence is important. Yes, El is important and helps explain a wide range of positive outcomes. But emotional intelligence isn't the overall cure or panacea that I naively thought it might be. My colleagues and I, first at Duke University, and more recently at Florida State University, have come to recognize that it takes more than just emotional intelligence for adolescents to be successful in life (Pfeiffer, 2013a, 2013b, 2017). Our careful review of the empirical research literature also informed us that it isn't that easy or simple to increase a person's level of emotional intelligence (Matthews, Lin, Zeidner, \& Roberts, 2017; Zeidner \& Mathews, 2017). This was initially disappointing, but nonetheless very helpful findings from the extant research literature on emotional intelligence, as we pondered how we could be helpful in enhancing the well-being and success of gifted youth (Pfeiffer, 2017).

We came to recognize in our work that gifted adolescents who are successful, who have friends and academically perform at high levels, adolescents who see meaning in their lives, and adolescents who report high levels of subjective well-being, all have three things going for them (Sharp, Niemiec, \& Lawrence, 2017). These three things I first called "the strengths of the heart triad". The triad consists of:

- Well-developed social skills;

- Sturdy and robust character strengths, such as empathy, compassion, optimism, a sense of humor, love-of-learning; and 
- Clear-cut ability to understand, read, and control their own, and others' feelings - what we had been viewing as emotional intelligence.

All three of these important psychological constructs, the triad of well-developed social skills, sturdy and robust character strengths, and clear-cut evidence for emotional intelligence, make a huge difference in the lives of gifted adolescents (Proyer, Gander, \& Tandler, 2017). This is a bit overstated, but we felt like we had found what we believed was the "Holy Grail" to ensure the success and psychological well-being of gifted youth!

My graduate students and I began investigating, and then calling, this triad of three constructs by the almost mystical term, "strengths of the heart". And as I shared this concept in talks that I was giving, in the USA and globally, with psychologists and other mental health practitioners, educators, parents, and policy makers, the term caught on. People seemed to resonate to the idea that "strengths of the heart" made sense and were important to talk more about, investigate, and nurture. And we have been investigating and learning more about the power of "strengths of the heart" ever since!

A few research studies that we have investigated in my research lab at Florida State University that has helped us begin to better understand the construct of "strengths of the heart" include (Pfeiffer et al., 2016):

- We have investigated effective strategies to ignite the motivational flame among extraordinarily bright- gifted- adolescents. Some, but not all, gifted youth lack motivation, or a passion to learn or the desire to face challenges. These youth tend to display little persistence in the face of adversity, low levels of drive or frustration tolerance, and fledging commitment to difficult tasks. In our research lab, we have explored, for example, how to make homework assignments more enjoyable and also more challenging. We have explored how to emphasize mastery and a "growth mindset" - a term popularized by the psychologist, (Dweck, 2006). And we have explored ways to identify and use mentors from the community as role models to help motivate and excite gifted adolescents. Many call this focus "the new psychology of success and fulfilling one's potential" (Dweck, 2006).

- We have also investigated the degree to which emotional intelligence and self-efficacy predict success among graduate students training to become psychotherapists. One of our early investigations used an ability model of emotional intelligence to determine whether emotional intelligence leads to better client outcomes certainly an important and practical consequence of entering counseling! - Our research lab hopes to next explore ways in which beginning therapists and other healthcare providers, and even teachers, can promote and refine their emotional intelligence abilities. Of course, we also hope to explore just how much can one increase their level of emotional intelligence. As mentioned earlier, other research indicates that it's not so easy to change one's level of emotional intelligence. This is not really surprising, particularly if one embraces an ability model of emotional intelligence.

- Our research lab has also investigated if an adolescents' level of emotional intelligence and level of socio-economic status predict to their subjective well-being. Subjective well-being is a "hot concept" in the psychology field, and for good reason. The field is rich with examples of interventions such as mindfulness training, designed to increase subjective well-being (Niemiec, 2014). We also researched the extent to which age, race/ethnicity, and gender play moderating and/or mediating roles in the relationship between emotional intelligence and subjective well-being. We hope in the coming years to have enough data to publish on these important questions.

- Our research lab researched the long-term effects of peer victimization and social support on the current level of well-being of high ability college students. Too few studies, in our opinion, have looked at older gifted adolescent- the student in college. In one investigation, we examined how students in our Honors College at Florida State University are doing, and compared their profile of socio-emotional functioning with a non-Honors college students. 
- A particularly interesting line of research has been exploring whether teachers can reliably and validly measure students' level of emotional intelligence. I created a scale to measure emotional intelligence that is rated by the youth's teacher. This is the very first teacher rating scale of emotional intelligence. Preliminary findings suggest that the scale is easy-to-use by teachers, highly reliable, and consists of three factors (Valler \& Pfeiffer, undated). Our next line of research is exploring whether this teacher-completed emotional intelligence scale relates to important outcomes in the classroom - such as love of learning, frustration tolerance, commitment, classroom grades, and love of challenge. We hope so. But we don't yet have the data to support our optimism and as-yet untested hypotheses! And we are also interested in exploring whether this teacher-completed emotional intelligence scale predicts to outcomes in the real social world outside of the classroom. We think that it should, but we realize that these optimistic hypotheses have yet to be scientifically tested. We are also working with colleagues in other countries who have translated my emotional intelligence scale and are now exploring the psychometric properties of the measure -, it's reliability, factor structure, validity, and utility as a tool that can help educators, parents, and psychologists better understand the inner world of the gifted child and adolescent.

- In close collaboration with a research lab school affiliated with Florida State University, we have begun to explore best ways to promote subjective well-being, optimism, gratitude, and compassion among adolescents. Our research lab has been reviewing the literature on individuallyand group-administered tactics, techniques, and interventions that are effective in promoting strengths of the heart (Sharp et al., 2017).

- A huge and complex research question that we are just beginning to grapple with is whether there are a particular set of character strengths that best predicts to success in later life among the gifted. For example, might empathy, gratitude, open-mindedness, kindness, honesty, and humility be the six "signature character strengths" that are most important for parents and educators to pay attention to? In all honesty, I suspect that we will find that there isn't one algorithm that works for all gifted youth. And, really, why should we think that one combination of signature character strengths would be equally powerful for each-andevery gifted youth! We suspect that personality, temperament, gender, family factors, and type of gifts all will play a contributing role in whatever combination of character strengths are mostand least- important in the lives of gifted youth. One line of research launched in our research lab that is particularly provocative and fascinating is whether parents and teachers share the same view the relative importance of the different character strengths. For example, we have explored whether parents might have a very different 'top six' list of most important character strengths, when compared to their adolescent's teacher's 'top six' list? And how do these two top six lists matchup with the adolescents! A related and equally fascinating research question is this: What if, for some gifted youth, there are significant differences in the comparative rankings of important character strengths by their parents, their teacher, and themselves? Do kids who have more disparate teacher: parent: self-character strength ratings lead to a weaker, or perhaps a stronger overall impact on the life of the gifted adolescent? Another way of asking this is: What is the most synergistic way to have the influence of home and school positively impact upon the development of an adolescent's character and virtues? This is an admittedly complex phenomenon, and we realize that we need to collect data on a huge sample of adolescents and their parents and teachers to begin unraveling the mystery behind the development of character strength and virtues (Peterson \& Seligman, 2004). In our own preliminary research, we have invited teachers and parents to rate the relative importance of a list of adjectives describing both "strengths of the head", such as 'imaginative', 'curious', and 'brilliant', and adjectives describing "strengths of the heart", such as 'caring', 'generous', 'compassionate', and 'kind'.

- Finally, in our research lab we are exploring whether- and to what degree, do gifted adolescents differ from their non-gifted peers in terms of 
socio-emotional functioning? For example, we have had gifted and non-gifted adolescents, their teachers and their parents, complete measures on motivational mindset, belongingness, loneliness, perfectionism, life satisfaction, and self-esteem. We hope that our research within this area helps shed some further light on "the whole gifted child", including a peek at their heart and soul, and not exclusively their head (Pfeiffer, 2013a, 2013b, 2015).

\section{Conclusion}

Taken together, we hope that our research enterprise can contribute in a real and meaningful way to furthering the gifted field's understanding of the social and emotional world of gifted adolescents. The questions that we are asking about strengths of the heart, although founded in developmental theory, are essentially applied questions. They are questions that have clear and concrete implications for translating our research into practice. We are excited about our work, both in the USA and internationally.

\section{References}

Dweck, C. S. (2006). Mindset: The new psychology of success. New York: Ballantine Books.

Matthews, G., Lin, J., Zeidner, M., \& Roberts, R. D. (2017). Emotional intelligence and giftedness. In S. I. Pfeiffer, E. Shaunessy-Dedrick, \& M. Foley-Nicpon (Eds.), APA handbook of giftedness and talent (pp.585-600). Washington, DC: APA Books.

Niemiec, R. M. (2014). Mindfulness and character strengths. Boston: Hogrefe Publishing Company.
Peterson, C., \& Seligman, M. E. P. (2004). Character strengths and virtues. New York: Oxford University Press.

Pfeiffer, S. I. (2001). Emotional intelligence: Popular but elusive construct. Roeper Review, 23, 138-142.

Pfeiffer, S. I. (2009). The gifted: Clinical challenges for child psychiatry. Journal of the American Academy of Child and Adolescent Psychiatry, 48, 787-790.

Pfeiffer, S. I. (2013a). Lessons learned from working with high-ability students. Gifted Education International, 29(1), 86-97.

Pfeiffer, S. I. (2013b). Serving the gifted. New York: Routledge.

Pfeiffer, S. I. (2015). Essentials of gifted assessment. Hoboken: Wiley.

Pfeiffer, S. I. (2017). Success in the classroom and in life: Focusing on strengths of the head and strengths of the heart. Gifted Education International, 33(2), 95-101.

Pfeiffer, S. I., Valler, E., Burko, J., Yarnell, J., Branagan, A., Smith, S. M., ... Saintil, M. (2016). Focusing on strengths of the heart in understanding success and psychological well-being of high-ability students. Austin Child \& Adolescent Psychiatry, 1(1), 1002-1003.

Proyer, R. T., Gander, F., \& Tandler, N. (2017). Strengthbased interventions: Their importance in application to the gifted. Gifted Education International, 33(2), 118-130.

Sharp, J. E., Niemiec, R. M., \& Lawrence, C. (2017). Using mindfulness-based strengths practices with gifted populations. Gifted Education International, 33(2), 131-144.

Valler, E., \& Pfeiffer, S. I. (unpublished manuscript). Preliminary reliability, factor structure of the Pfeiffer Emotional Intelligence Scale.

Zeidner, M., \& Matthews, G. (2017). Emotional intelligence in gifted students. Gifted Education International, 33(2), 163-182.

Received: October 31, 2017

Approved: December 15, 2017 